\title{
THE EFFECT OF PHYSICAL ACTIVITY ON PULMONARY FUNCTION IN PATIENTS WITH PECTUS EXCAVATUM
}

\section{WPŁYW AKTYWNOŚCI FIZYCZNEJ NA FUNKCJE PŁUC U PACJENTÓW Z LEJKOWATĄ KLATKĄ PIERSIOWĄ}

\author{
Wioletta Mikul'ákovái( ${ }^{(B, C, D, E, F, G)}$, Lucia Kendrová ${ }^{1(C, D, E)}$, Stanislava Kuželová $2(A, B, F)$, \\ Miloslav Gajdoš ${ }^{1(D, E)}, J^{\prime}$ akub Čuj ${ }^{1(B, C)}$, Martin Mikulák ${ }^{3(D, E)}$, Yuriy Peresta ${ }^{1(E, F)}$ \\ ${ }^{1}$ Department of Physiotherapy, Faculty of Health Care, University of Prešov, Slovakia \\ ${ }^{2}$ Secondary Medical School, Košice, Slovakia \\ ${ }^{3}$ Cardiocenter, Faculty Hospital J.A. Reiman, Prešov, Slovakia
}

Authors' contribution Wkład autorów:

A. Study design/planning zaplanowanie badań B. Data collection/entry zebranie danych

C. Data analysis/statistics dane - analiza i statystyki D. Data interpretation interpretacja danych E. Preparation of manuscript przygotowanie artykułu F. Literature analysis/search wyszukiwanie i analiza literatury G. Funds collection zebranie funduszy
Tables: 6

Figures: 0

References: 48

Submitted: 2020 Sep 30

Accepted: 2020 Nov 4

\section{Summary}

Background. The aim of this study was to determine the impact of the level of physical activity on pulmonary function in patients with pectus excavatum.

Material and methods. This study included 47 patients diagnosed with pectus excavatum, with a median age of 19 years (min. 17 years, max. 26 years). The degree of deformity was evaluated clinically by anthropometric measurement. Spirometry was used for the evaluation of pulmonary function. The demographic, clinical data, and experience of patients with sporting activity were examined using a questionnaire. The self-reported International Physical Activity Questionnaire short form (IPAQ-SF) was used to determine physical activity levels.

Results. With higher physical activity, there was statistically significant higher inspiratory vital capacity (IVC) (rho=0.628), forced vital capacity (FVCex) (rho=0.455), and forced expiratory volume in 1 second $(\mathrm{FEV})$ (rho=0.356). A statistically significant relationship was observed between deformity rate and spirometric parameters for $\mathrm{FEV}_{1}(\mathrm{p}=0.011)$, maximal expiratory flow rate of 75\% FVC (MEF75) ( $p<0.0001)$, and peak expiratory flow (PEF) $(p<0.0001)$.

Conclusions. Respiratory functions of patients with chest deformity are positively influenced by physical activity.

Keywords: pectus excavatum, spirometry, physical activity, pulmonary function

\section{Streszczenie}

Wprowadzenie. Celem badania było ustalenie wpływu poziomu aktywności fizycznej na funkcje płuc u pacjentów z lejkowatą klatką piersiową.

Materiał i metody. W badaniu wzięło udział 47 pacjentów ze zdiagnozowaną lejkowatą klatką piersiową. Średnia wieku wynosiła 19 lat (minimum 17, maksimum 26 lat). Stopień deformacji został określony klinicznie za pomocą pomiaru antropometrycznego. Do określenia funkcji płuc zastosowano spirometrię. Dane demograficzne, kliniczne oraz związane z aktywnością sportową pacjentów zostały zebrane w postaci ankiety, natomiast w celu ocenienia poziomu aktywności fizycznej wykorzystano skrócony Międzynarodowy Kwestionariusz Aktywności Fizycznej (IPAQ-SF) wypełniony przez pacjentów.

Wyniki. Wraz ze wzrostem aktywności fizycznej pacjentów zaobserwowano statystycznie istotny wzrost wdechowej pojemności życiowej (IVC) (rho=0,628), natężonej objętości wydechowej (FVCex) (rho=0,455) i objętości wydechowej pierwszosekundowej $\left(\mathrm{FEV}_{1}\right)$ (rho=0,356). Zaobserwowany związek pomiędzy stopniem deformacji i parametrami spirometrycznymi okazał się statystycznie istotny dla zmiennych: FEV ${ }_{1} \quad(p=0.011)$, maksymalnego przepływu wydechowego o 75\% FVC (MEF75) $(p<0,0001)$ i szczytowego przepływu wydechowego (PEF) $(\mathrm{p}<0,0001)$.

Wnioski. Aktywność fizyczna ma pozytywny wpływ na funkcje oddechowe pacjentów $\mathrm{z}$ deformacją klatki piersiowej.

Słowa kluczowe: lejkowata klatka piersiowa, spirometria, aktywność fizyczna, funkcje płuc 


\section{Introduction}

Physical activity is an important part of a healthy lifestyle. There is much evidence outlining the benefits of regular physical activity. It is an important factor in the prevention of cardiovascular, cerebrovascular, and metabolic disease, as well as cancer, and is involved in improving overall physical condition and mental health [1-3]. The prevalence of physical inactivity has major implications for the overall health of the population and the prevalence of non-communicable diseases $[4,5]$. Some authors report that the level of physical activity positively affects pulmonary function [6-9]. At the same time, many studies have shown that spirometric parameters decline noticeably due to a sedentary lifestyle $[6,10,11]$.

Pectus excavatum is a common deformity of the rib cage and the front wall of the chest; Bartl [12] and Jaroszewski et al. $[13,14]$ postulate that pectus excavatum is, in fact, the most common type of congenital deformity, and is present in up to $90 \%$ of all congenital chest deformities. Several studies have examined the effect of chest deformities on cardiopulmonary function [15-20]. However, there is still debate amongst the medical community whether actual pulmonary limitations exist in pectus excavatum patients. Jaroszewski [13] and Fonkalsrud and Beanes [20] describe the following symptoms in patients with congenital chest deformities: exertional shortness of breath, physical exercise limitation, frequent respiratory infections, bronchial asthma, exercise chest pain, progressive fitness loss, palpitations, tachycardia, and increased fatigue. These factors, along with the psychological problems associated with changing the appearance of the chest, negatively affect the relationship of patients to physical activity [21,22].

Current literature lacks detail of the daily level of physical activity of patients with pectus excavatum. Few studies have focused on the quantitative measurement of physical or sporting activity of these patients; these data tend to be captured primarily in studies evaluating the success of surgical treatment [21,23]. We believe that mapping the presented problem can contribute to an understanding of some determinants affecting pulmonary function in these patients. Therefore, the objective of this study was to determine the impact of the level of physical activity on pulmonary function in patients with pectus excavatum. The following hypothesis was put forward: physical activity positively affects pulmonary function in patients with pectus excavatum.

\section{Material and methods}

The research sample consisted of 47 patients diagnosed with pectus excavatum. Data were collected from June 2019 until January 2020. The survey was conducted at the University of Prešov in Prešov and the Center of Preventive and Sports Medicine at the Third Internal Clinic UNLP, Tr. SNP 1, Košice, Slovakia.

The inclusion criteria in the study were as follows: 1.) diagnosis of pectus excavatum by doctor; 2.) written informed consent to participate in the study; 3.) no respiratory disease 2 weeks before planned spirometry examination. The exclusion criteria were as follows: 1.) pectus carinatum, plat chest, or other complex anomaly; 2.) acute illness 2 weeks before planned spirometry examination; 3.) unwillingness to cooperate; 4.) no diagnosis of pectus excavatum deformity by doctor; 5.) other factors that prevent patients from participating in the study.

To evaluate the effect of chest deformity on the respiratory system we divided the group into three groups according to severity: group A (first stage - slight deformity), group B (second stage - medium deformity) and group C (third stage - severe deformity). We divided the patients into groups according to the anthropometric measurement [24].

We diagnosed 51 patients with pectus excavatum. Due to the relatively low representation of patients in the group with severe deformity (4 patients) we present the results of this study only in a group of patients with slight and medium chest deformity (47 males).

\section{Measurement}

The data collected were obtained by the diagnostic survey method implementing tools such as the authors' questionnaire, the standardized questionnaire International Physical Activity Questionnaire short form (IPAQ$\mathrm{SF}$ ), and objective evaluation of endpoints. The questionnaire designed by the authors contained questions to obtain demographics, clinical data, and level of sporting activity in early and middle adolescence. Based on the answers we evaluated the following data: age and sex of respondents, smoking or its length, and the type and length of sporting activity practiced in early and middle adolescence. Sporting activity was defined as belonging to a sports club and training carried out twice a week or more often.

The IPAQ-SF was used to evaluate participants' physical activity. The IPAQ-SF is a 9-item scale, assessing the minutes spent in vigorous and moderately intense activity and walking during the last 7 days. The number of 
minutes spent sitting on weekdays in the past 7 days is also assessed. For all categories, patients had to define on how many days and how many minutes they spent at a specific activity category. According to the IPAQSF scoring protocol, the data collected were converted to Metabolic Equivalent Task: total minutes over last 7 days spent on sitting, walking, moderate, and vigorous activity, and were multiplied by 1.6, 3.3, 4.0, and 8.0, respectively, to create MET scores for each activity level. Besides these 4 sub scores, a total score is calculated by counting the METs-minutes of the 3 categories (walking, moderate, and vigorous activity) together. Therefore, IPAQ-SF scores are reported in MET minutes/week (MET-min/wk.) [25,26].

Among the components of the objective examination we included: height and weight of the respondents, type of chest deformity, rate of chest deformity, and spirometric examination results. The type of chest deformity was evaluated clinically. In this study, weight was measured using a digital scale (kg), whilst height was measured by stadiometer $(\mathrm{cm})$.

Anthropometric measurements were made to evaluate the rate of chest deformity. We used external chest measurements to minimize exposure to radiation. Pectus excavatum deformities are divided into three degrees according to changes [24]:

- first stage: inversion is limited to xiphisternal joint, sagittal diameter is reduced by less than 10\%;

- second stage: inverted lower part of sternum and adjacent rib cartilage, sagittal diameter is shortened by $10-20 \%$;

- third stage: the whole body of the sternum (except manubria) and the adjacent rib cartilage are invoked in their entirety (often the bone parts of the ribs are invoked), the sagittal diameter being reduced by more than $20 \%$.

To determine the percentage reduction in the sagittal diameter of the chest, we made two measurements in the sagittal plane. The first measurement was defined as the largest anteroposterior diameter at the level of the distal third of the sternum, and the second measurement was the largest depth at the same level. On the basis of these measurements, we determined the percentage of change in the inclination [24].

Spirometric examination was carried out in the Center of Preventive and Sports Medicine at III. Internal Clinic UNLP, Tr. SNP 1, Košice, Slovakia. Ganshorn PowerCube LF8.5M SR2 certified computer spirometry system was used for functional examination of the lungs. Functional diagnosis of our respondents' lungs included the following parameters: inspiratory vital capacity (IVC), forced expiratory capacity (FVCex), forced expiratory volume for 1 second $\left(\mathrm{FEV}_{1}\right)$, Tiffeneau index $\left(\mathrm{FEV}_{1} / \mathrm{IVC}\right)$, maximal expiratory flow rate of 25\%, 50\%, 75\% FVC (MEF25, MEF50, MEF75), and peak exhalation flow (PEF).

This study was approved by the facility ethics committee. Participation in this study was anonymous and voluntary. All respondents or legal guardians of respondents who were under 18 at the time of the survey signed the Informed Consent of Underage Respondents or Informed Consent of the Underage Respondents' Legal Representatives. All procedures performed in studies involving human participants were in accordance with the ethical standards of the institutional and/or national research committee and with the $1964 \mathrm{Helsinki}$ Declaration and its later amendments or comparable ethical standards.

\section{Statistical Analyses}

Data normality were assessed using the Shapiro-Wilk test. All variables did not follow a normal distribution, therefore nonparametric analyses were used. Qualitative data are presented as median, minimum, and maximum. Categorical data are presented as number and percentage. To assess intergroup differences in the average level of numerical features the Kruskal-Wallis test and the Mann-Whitney U-test, were used. Correlations between evaluated factors physical activity and spirometric parameters were analyzed using the Spearman coefficient. The strength of the dependencies was interpreted according to a scheme [27] where values below 0.3 are considered to be very weak (negligible) dependence; $0.3 \leq r<0.5$ are weak; $0.5 \leq r<0.7$ are moderate; $0.7 \leq r<0.9$ are strong and $r \geq 0.9$ are very strong dependence. For all calculations, the statistical significance $\mathrm{p}<0.05$ was considered significant with a 95\% confidence interval. Statistical analyses was performed using IBM SPSS 19 software.

\section{Results}

In Table 1 we present the basic demographic and clinical data of respondents $(n=47)$ informing us about their gender, age, height, weight, type of chest deformity, and smoking or its length. Information on the respondents' sporting activity in early and middle adolescence is also presented. Respondents were all male, with a median age of 19 years (ranging from 17 to 26 years), height of $178 \mathrm{~cm}$ (ranging from 170 to $190 \mathrm{~cm}$ ) and weight of $70 \mathrm{~kg}$ 
(ranging from 56 to $87 \mathrm{~kg}$ ). Of the 47 respondents, 31 respondents had a congenital type of deformity - pectus excavatum (66.00\%), and 16 respondents had a congenital type of deformity pectus excavatum with acquired type in scoliosis (34.00\%). 31 respondents did not smoke (66.00\%), 7 respondents smoked occasionally (14.90\%), and 9 respondents smoked up to 5 cigarettes a day (19.10\%). The median smoking time of our respondents was 0.00 years. $31(66.00 \%)$ had a second stage of chest deformity (Group B), and 16 patients (34.00\%) had the first stage of deformity (Group A). In early and middle adolescence, 20 respondents focused on team sport (13 football, 2 - hockey, 2 - water polo, 2 - volleyball, 1 - basketball) (42.55\%), 12 respondents on individual sport (4 - swimming, 2 - dance, 2 - cycling, 3 - martial arts, 1 - athletics) (25.53\%). 15 respondents did not engage in any sporting activity (31.91\%). There were no differences in median gender, height, smoking status or its length, nor type and length of sporting activity in early and middle adolescence.

Table 1. Comparison of baseline characteristics in respective groups of subjects

\begin{tabular}{|c|c|c|c|c|c|}
\hline Parameters & Together & Group A & Group B & z-score & p-value \\
\hline \multicolumn{6}{|c|}{ Number of patients } \\
\hline n (\%) & 47 & $16(34.0 \%)$ & $31(66.0 \%)$ & - & - \\
\hline \multicolumn{6}{|c|}{ Gender } \\
\hline Men (n) & 47 & 16 & 31 & 0.000 & 1.000 \\
\hline \multicolumn{6}{|c|}{ Age (years) } \\
\hline Median & 19.00 & 18.00 & 19.00 & \multirow{2}{*}{-1.770} & \multirow{2}{*}{0.077} \\
\hline Min. - Max. & $17-26$ & $17-21$ & $17-26$ & & \\
\hline \multicolumn{6}{|c|}{ Height (cm) } \\
\hline Median & 178 & 177 & 178 & \multirow{2}{*}{-1.131} & \multirow{2}{*}{0.896} \\
\hline Min. - Max. & $170-190$ & $170-190$ & $171-182$ & & \\
\hline \multicolumn{6}{|c|}{ Weight (kg) } \\
\hline Median & 70.00 & 76.00 & 69.50 & \multirow{2}{*}{-1.956} & \multirow{2}{*}{0.051} \\
\hline Min. - Max. & $56-87$ & $57-87$ & $56-77$ & & \\
\hline \multicolumn{6}{|c|}{ Type of chest deformity $n(\%)$} \\
\hline Pectus excavatum & $31(66.0 \%)$ & $10(62.5 \%)$ & $21(67.7 \%)$ & \multirow[b]{2}{*}{-3.679} & \multirow[b]{2}{*}{$0.000^{*}$} \\
\hline $\begin{array}{l}\text { Pectus excavatum } \\
\text { with scoliosis }\end{array}$ & $16(34.0 \%)$ & $6(37.5 \%)$ & $10(32.3 \%)$ & & \\
\hline \multicolumn{6}{|c|}{ Smoking status n (\%) } \\
\hline No, I don't smoke & $31(66.0 \%)$ & $9(56.3 \%)$ & $22(71.0 \%)$ & \multirow{3}{*}{-0.134} & \multirow{3}{*}{0.894} \\
\hline Yes, occasionally & $7(14.9 \%)$ & $7(43.7 \%)$ & $0(0.0 \%)$ & & \\
\hline $\begin{array}{c}\text { Yes, up to } 5 \\
\text { cigarettes a day }\end{array}$ & $9(19.1 \%)$ & $0(0.0 \%)$ & $9(29.0 \%)$ & & \\
\hline \multicolumn{6}{|c|}{ Smoking time (years) } \\
\hline Median & 0.0 & 0.0 & 0.0 & \multirow{2}{*}{-0.617} & \multirow{2}{*}{0.537} \\
\hline Min. - Max. & $0-6$ & $0-3$ & $0-6$ & & \\
\hline \multicolumn{6}{|c|}{ Duration of SA in early and middle adolescence (years) } \\
\hline Median & 4.00 & 2.00 & 7.00 & \multirow{2}{*}{-2.186} & \multirow{2}{*}{ 0.029* } \\
\hline Min. - Max. & $0-12$ & $2-10$ & $0-12$ & & \\
\hline \multicolumn{6}{|c|}{ Type of SA in early and middle adolescence $n(\%)$} \\
\hline Team sport & $20(42.55 \%)$ & $9(56.25 \%)$ & $11(35.48 \%)$ & \multirow{3}{*}{-1.812} & \multirow{3}{*}{0.070} \\
\hline Individual sport & $12(25.53 \%)$ & $5(31.25 \%)$ & $7(22.5 \%)$ & & \\
\hline $\begin{array}{c}\text { I didn't engage } \\
\text { in PA }\end{array}$ & 15 (31.91\%) & $2(12.5 \%)$ & 13 (41.93) & & \\
\hline
\end{tabular}

Notes: SA - sporting activity; PA - physical activity; Max. - maximum value; Min. - minimum value; Mann-Whitney U-test (z-score); p - probability value. * Significant at the 0.05 level.

From our measurements, we found that at slight and medium deformation, the median values of IVC were 84\%; there was no significant difference ( $p>0.05)$. The slight deformity group achieved best values of FVCex, $\mathrm{FEV}_{1}, \mathrm{MEF75}$, and PEF. The relationship between the observed deformity rate and spirometry parameters was statistically significant for $\mathrm{FEV}_{1}(\mathrm{p}=0.011)$, MEF75 ( $\left.\mathrm{p}<0.0001\right)$, PEF $(\mathrm{p}<0.0001)$. MEF50 showed the same median values of $90 \%$ in patients with slight and medium (Table 2). 
Table 2. Comparison of chest deformity on spirometric parameters in respective study groups

\begin{tabular}{|c|c|c|c|c|c|}
\hline Parameters (\%) & $\begin{array}{c}\text { Together } \\
\mathrm{n}=47\end{array}$ & $\begin{array}{c}\text { Group A } \\
n=16\end{array}$ & $\begin{array}{c}\text { Group B } \\
n=31\end{array}$ & z-score & p-value \\
\hline \multicolumn{6}{|c|}{ IVC } \\
\hline Median & 84.00 & 84.00 & 84.00 & \multirow{2}{*}{-1.632} & \multirow{2}{*}{0.103} \\
\hline Min. - Max. & $60.00-130$ & $80.00-130.00$ & $60.00-101.00$ & & \\
\hline \multicolumn{6}{|c|}{ FVCex } \\
\hline Median & 90.00 & 91.00 & 90.00 & \multirow{2}{*}{-1.915} & \multirow{2}{*}{0.056} \\
\hline Min. - Max. & $59.00-129.00$ & $85.00-129.00$ & $59.00-108.00$ & & \\
\hline \multicolumn{6}{|c|}{ FEV $_{1}$} \\
\hline Median & 94.00 & 98.00 & 94.00 & \multirow{2}{*}{-2.536} & \multirow{2}{*}{$0.011^{*}$} \\
\hline Min. - Max. & $67.00-128.00$ & $90.00-128.00$ & $67.00-113.00$ & & \\
\hline \multicolumn{6}{|c|}{$\mathrm{FEV}_{1} / \mathrm{IVC}$} \\
\hline Median & 108.00 & 105.00 & 108.00 & \multirow{2}{*}{-1.177} & \multirow{2}{*}{0.239} \\
\hline Min. - Max. & $91.00-132.00$ & $91.00-115.00$ & $102.00-132.00$ & & \\
\hline \multicolumn{6}{|c|}{ MEF25 } \\
\hline Median & 88.00 & 88.00 & 91.00 & \multirow[t]{2}{*}{-0.496} & \multirow{2}{*}{0.620} \\
\hline Min. - Max. & $66.00-174.00$ & $76.00-113.00$ & $66.00-174.00$ & & \\
\hline \multicolumn{6}{|c|}{ MEF50 } \\
\hline Median & 90.00 & 90.00 & 90.00 & \multirow{2}{*}{-8.553} & \multirow{2}{*}{0.580} \\
\hline Min. - Max. & $53.00-125.00$ & $78.00-125.00$ & $53.00-114.00$ & & \\
\hline \multicolumn{6}{|c|}{ MEF75 } \\
\hline Median & 87.00 & 104.00 & 79.00 & \multirow{2}{*}{-4.873} & \multirow{2}{*}{$0.000^{*}$} \\
\hline Min. - Max. & $34.00-115.00$ & $98.00-115.00$ & $34.00-105.00$ & & \\
\hline \multicolumn{6}{|c|}{ PEF } \\
\hline Median & 89.00 & 93.00 & 77.00 & \multirow{2}{*}{-4.376} & \multirow{2}{*}{$0.000^{*}$} \\
\hline Min. - Max. & $42.00-113.00$ & $91.00-113.00$ & $42.00-106.00$ & & \\
\hline
\end{tabular}

Notes: Max. - maximum value; Min. - minimum value; Mann-Whitney U-test (z-score); p - probability value. * Significant at the 0.05 level.

Analyses of the data obtained through the IPAQ-SF total activity level survey showed that patients with slight deformity gained an average 1510 (198-6252) MET (min/wk.), and 1572 (487.5-6080) MET (min/wk.) with medium deformity. There was no significant difference in activity levels in terms of the rate of chest deformity ( $p>0.05$ ). Median vigorous physical activity levels were 720 MET (min/wk.) and 560 MET (min/wk.), respectively. Patients in the slight deformity group spent a median of 360 MET (min/wk.) in moderate physical activity, whilst the medium deformity group spent 320 MET (min/wk.) There were no significant differences in physical activity levels between groups in the IPAQ-SF categories (Table 3).

Table 3. Comparison of level of physical activity in areas (IPAQ-SF) in respective groups of subjects

\begin{tabular}{|c|c|c|c|c|c|}
\hline $\begin{array}{c}\text { Parameters } \\
\text { (MET-min/wk.) }\end{array}$ & $\begin{array}{c}\text { Together } \\
\mathrm{n}=47\end{array}$ & $\begin{array}{c}\text { Group A } \\
\mathrm{n}=16\end{array}$ & $\begin{array}{c}\text { Group B } \\
n=31\end{array}$ & z-score & p-value \\
\hline \multicolumn{6}{|c|}{ Vigorous PA } \\
\hline Median & 720.00 & 720.00 & 560.00 & \multirow{2}{*}{-0.282} & \multirow{2}{*}{0.778} \\
\hline Min. - Max. & $0-5760$ & $0-3600$ & $0-5760$ & & \\
\hline \multicolumn{6}{|c|}{ Moderate PA } \\
\hline Median & 360.00 & 360.00 & 320.00 & \multirow{2}{*}{-0.271} & \multirow{2}{*}{0.786} \\
\hline Min. - Max. & $0-2520$ & $0-2520$ & $40-1800$ & & \\
\hline \multicolumn{6}{|c|}{ Walking } \\
\hline Median & 247.50 & 231.00 & 247.50 & \multirow{2}{*}{-0.350} & \multirow{2}{*}{0.727} \\
\hline Min. - Max. & $0-1150$ & $132-1150$ & $0-594$ & & \\
\hline \multicolumn{6}{|c|}{ IPAQ SF total PA } \\
\hline Median & 1510.00 & 1510.00 & 1572.00 & \multirow{2}{*}{-0.112} & \multirow{2}{*}{0.911} \\
\hline Min. - Max. & $198-6252$ & $198-6252$ & $487.5-6080$ & & \\
\hline \multicolumn{6}{|c|}{ Sedentary } \\
\hline Median & 600.00 & 540.00 & 630.00 & \multirow{2}{*}{-2.114} & \multirow{2}{*}{ 0.034* } \\
\hline Min. - Max. & $375-820$ & $375-770$ & $420-820$ & & \\
\hline
\end{tabular}

Notes: IPAQ-SF - International Physical Activity Questionnaire short form; PA - physical activity; MET - Metabolic Equivalent Task; Max. - maximum value; Min. - minimum value; Mann-Whitney U-test (z-score); $\mathrm{p}$ - probability value. * Significant at the 0.05 level. 
Analysis of the mean values for physical activity expressed in MET (min/wk.) showed that the highest weekly physical activity was noted among the non-smokers. No statistically significant differences were observed when analysis was performed with the consideration of smoking status (Table 4).

Table 4. Comparison of level of physical activity in areas (IPAQ-SF) in groups of subjects depending on smoking status

\begin{tabular}{|c|c|c|c|c|c|c|}
\hline $\begin{array}{c}\text { Parameters } \\
\text { (MET-min/wk.) }\end{array}$ & $\begin{array}{c}\text { Together } \\
n=47\end{array}$ & $\begin{array}{c}\text { Non-smoker } \\
n=31\end{array}$ & $\begin{array}{c}\text { Occasional } \\
\text { smoker } \\
n=7\end{array}$ & $\begin{array}{c}\text { Smoker } \\
n=9\end{array}$ & H-statistic & p-value \\
\hline \multicolumn{7}{|c|}{ Vigorous PA } \\
\hline Median & 720.00 & 960.00 & 240.00 & 360.00 & \multirow{2}{*}{1.525} & \multirow{2}{*}{0.467} \\
\hline Min. - Max. & $0-5760$ & $0-5760$ & $0-720$ & $40-2240$ & & \\
\hline \multicolumn{7}{|c|}{ Moderate PA } \\
\hline Median & 360.00 & 480.00 & 240.00 & 360.00 & \multirow{2}{*}{3.903} & \multirow{2}{*}{0.142} \\
\hline Min. - Max. & $0-2520$ & $0-2520$ & $120-360$ & $200-1400$ & & \\
\hline \multicolumn{7}{|c|}{ Walking } \\
\hline Median & 247.50 & 247.50 & 231.00 & 247.50 & \multirow{2}{*}{2.389} & \multirow{2}{*}{0.303} \\
\hline Min. - Max. & $0-1150$ & $0-594$ & $198-1150$ & $66-528$ & & \\
\hline \multicolumn{7}{|c|}{ IPAQ SF total PA } \\
\hline Median & 1510.00 & 1572.00 & 1311.00 & 1328.00 & \multirow{2}{*}{2.051} & \multirow{2}{*}{0.141} \\
\hline Min. - Max. & $198-6252$ & $198-6252$ & $438-1510$ & $786-2737$ & & \\
\hline \multicolumn{7}{|c|}{ Sedentary } \\
\hline Median & 600.00 & 630.00 & 510.00 & 580.00 & \multirow{2}{*}{1.549} & \multirow{2}{*}{0.461} \\
\hline Min. - Max. & $375-820$ & $375-820$ & $480-540$ & $420-727$ & & \\
\hline
\end{tabular}

Notes: IPAQ-SF - International Physical Activity Questionnaire short form; PA - physical activity; MET - Metabolic Equivalent Task; Max. - maximum value; Min. - minimum value; Kruskal-Wallis test (H-statistic); p - probability value.

Analysis of respondents' physical activity, with consideration of chest deformity, showed that subjects with pectus excavatum without scoliosis spent more time engaging in physical activity than those with pectus excavatum with scoliosis. There were no significant differences in physical activity levels between groups in the IPAQ-SF categories (Table 5).

Table 5. Comparison of level of physical activity in areas (IPAQ-SF) in groups of subjects depending on chest deformity

\begin{tabular}{|c|c|c|c|c|c|}
\hline $\begin{array}{c}\text { Parameters } \\
\text { (MET-min/wk.) }\end{array}$ & $\begin{array}{c}\text { Together } \\
\mathbf{n}=47\end{array}$ & $\begin{array}{c}\text { Pectus } \\
\text { excavatum } \\
n=31\end{array}$ & $\begin{array}{c}\text { Pectus } \\
\text { excavatum with } \\
\text { scoliosis } \\
n=16\end{array}$ & z-score & p-value \\
\hline \multicolumn{6}{|c|}{ Vigorous PA } \\
\hline Median & 720.00 & 720.00 & 460.00 & \multirow{2}{*}{-0.676} & \multirow{2}{*}{0.499} \\
\hline Min. - Max. & $0-5760$ & $0-4320$ & $0-5760$ & & \\
\hline \multicolumn{6}{|c|}{ Moderate PA } \\
\hline Median & 360.00 & 360.00 & 350.00 & \multirow{2}{*}{-0.068} & \multirow{2}{*}{0.946} \\
\hline Min. - Max. & $0-2520$ & $40-2520$ & $0-2380$ & & \\
\hline \multicolumn{6}{|c|}{ Walking } \\
\hline Median & 247.50 & 247.00 & 231.00 & \multirow{2}{*}{-0.056} & \multirow{2}{*}{0.955} \\
\hline Min. - Max. & $0-1150$ & $0-1150$ & $0-1030$ & & \\
\hline \multicolumn{6}{|c|}{ IPAQ SF total PA } \\
\hline Median & 1510.00 & 1572.00 & 1419.00 & \multirow{2}{*}{-0.427} & \multirow{2}{*}{0.669} \\
\hline Min. - Max. & $198-6252$ & $438-6252$ & $198-6252$ & & \\
\hline \multicolumn{6}{|c|}{ Sedentary } \\
\hline Median & 600.00 & 615.00 & 587.50 & \multirow{2}{*}{-1.406} & \multirow{2}{*}{0.160} \\
\hline Min. - Max. & $375-820$ & $390-820$ & $375-770$ & & \\
\hline
\end{tabular}

Notes: IPAQ-SF - International Physical Activity Questionnaire short form; PA - physical activity; MET - Metabolic Equivalent Task; Max. - maximum value; Min. - minimum value; Mann-Whitney U (z-score); p - probability value. 


\section{Correlation analysis between spirometric parameters and selected factors of physical activity}

The results in Table 6 illustrate several significant relationships between physical activity and spirometric parameters. The following areas of the patients' physical activity were considered: level of physical activity and its areas, sports disciplines practiced in early and middle adolescence, and their length.

Table 6. Correlation coefficients describing the relationships between spirometric parameters and selected factors of physical activity

\begin{tabular}{|c|c|c|c|c|c|c|c|c|c|c|c|c|}
\hline \multirow[t]{2}{*}{ Parameters } & \multicolumn{2}{|c|}{$\begin{array}{c}\text { Vigorous PA } \\
\text { (MET-min/ } \\
\text { wk.) }\end{array}$} & \multicolumn{2}{|c|}{$\begin{array}{c}\text { Moderate PA } \\
\text { (MET-min/ } \\
\text { wk.) }\end{array}$} & \multicolumn{2}{|c|}{$\begin{array}{c}\text { Walking } \\
\text { (MET-min/ } \\
\text { wk.) }\end{array}$} & \multicolumn{2}{|c|}{$\begin{array}{l}\text { IPAQ-SF total } \\
\text { score } \\
\text { (MET-min/ } \\
\text { wk.) }\end{array}$} & \multicolumn{2}{|c|}{$\begin{array}{l}\text { Length of SA } \\
\text { in early } \\
\text { and middle } \\
\text { adolescence }\end{array}$} & \multicolumn{2}{|c|}{$\begin{array}{c}\text { Type of SA } \\
\text { in early } \\
\text { and middle } \\
\text { adolescence }\end{array}$} \\
\hline & rho & $\mathbf{P}$ & rho & p & rho & p & rho & $\mathbf{p}$ & rho & p & rho & p \\
\hline IVC & 0.452 & 0.001 & 0.374 & 0.010 & 0.327 & 0.025 & 0.628 & 0.000 & 0.283 & 0.054 & 0.088 & 0.558 \\
\hline FVCex & 0.313 & 0.032 & 0.484 & 0.001 & 0.120 & 0.422 & 0.455 & 0.001 & 0.355 & 0.014 & 0.158 & 0.290 \\
\hline $\mathrm{FEV}_{1}$ & 0.212 & 0.153 & 0.341 & 0.019 & 0.165 & 0.269 & 0.356 & 0.014 & 0.406 & 0.005 & 0.132 & 0.378 \\
\hline $\mathrm{FEV}_{1} / \mathrm{IVC}$ & -0.728 & 0.000 & -0.374 & 0.010 & -0.162 & 0.278 & -0.776 & 0.000 & -0.074 & 0.621 & -0.123 & 0.408 \\
\hline MEF25 & -0.008 & 0.956 & -0.033 & 0.825 & -0.086 & 0.563 & 0.010 & 0.944 & 0.072 & 0.628 & -0.293 & 0.046 \\
\hline MEF50 & 0.137 & 0.359 & 0.074 & 0.623 & -0.127 & 0.395 & 0.144 & 0.344 & 0.204 & 0.168 & -0.063 & 0.673 \\
\hline MEF75 & 0.158 & 0.287 & 0.068 & 0.649 & 0.083 & 0.581 & 0.198 & 0.182 & 0.332 & 0.023 & 0.219 & 0.139 \\
\hline PEF & -0.019 & 0.899 & 0.097 & 0.517 & -0.032 & 0.832 & 0.099 & 0.508 & 0.303 & 0.038 & 0.162 & 0.276 \\
\hline
\end{tabular}

Notes: IPAQ-SF - International Physical Activity Questionnaire short form; PA - physical activity; SA - sporting activity; MET - Metabolic Equivalent Task; rho - correlation coefficient; $\mathrm{p}$ - probability value.

Analysis of Spearman (rho) correlation coefficients showed that, with higher total activity level (IPAQ-SF total score), there was a significant increase in the values of: IVC (rho=0.628) - moderate positive correlation; FVCex (rho=0.455) - moderate positive correlation; and $\mathrm{FEV}_{1}($ rho=0.356) - weak positive correlation. With patients' higher physical activity, there was also statistically significant lower $\mathrm{FEV}_{1} / \mathrm{IVC}_{\text {( }}$ (rho=-0.776).

Vigorous physical activity also affected spirometric indices. Vigorous physical activity was positively correlated with the values of IVC (rho=0.452), FVCex (rho=0.313), and negatively correlated with the $\mathrm{FEV}_{1} /$ IVC (rho=-0.728). Moderate physical activity positively correlated with the values of IVC (rho=0.374), FVCex $(\mathrm{rho}=0.484), \mathrm{FEV}_{1}(\mathrm{rho}=0.341)$ and negatively correlated with the $\mathrm{FEV}_{1} / \mathrm{IVC}(\mathrm{rho}=-0.374)$. Walking positively correlated with the values of IVC (rho=0.327).

The length of SA in early and middle adolescence positively correlated with the values of FVCex (rho=0.355), FEV $_{1}$ (rho=0.406), MEF75 (rho=0.332), PEF (rho=0.303). The types of sports activities in early and middle adolescence negatively correlated with the MEF25 (rho=-0.293).

\section{Discussion}

In the study by Lawson et al. [28] patients with pectus excavatum were divided into two groups of differing

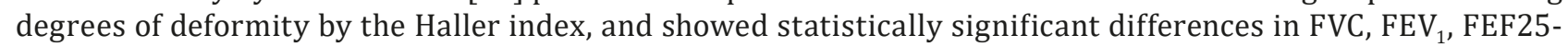
75 , and $\mathrm{FEV}_{1} / \mathrm{FVC}$. They showed that pulmonary function is related to the depth of sternal depression. The authors remain open to the question of the effect of the deformity rate on cardiopulmonary function at rest and during physical activity [28]. Abu-Tair et al. [29] concluded that the Haller index and correction index correlated statistically significantly with cardiopulmonary function and chest deformity rate of pectus excavatum. Kelly et al. [17] pointed out that people with a higher degree of deformity (higher Haller index) showed reduced pulmonary function. The authors found that patients who were evaluated for severe pectus excavatum on a clinical basis, showed that FVC, FEV , and FEF25-75 values were decreased by a mean of $15 \%$ below predicted value. Morshuis et al. [30], by long-term follow-up, investigated the extent of lung function limitation in patients with pectus excavatum and confirmed that it is limited. Total pulmonary capacity (TLC) and inspiratory vital capacity (IVC) had a significant relationship with age corrected (delta) sagittal chest diameter (lower vertebral index [LVI]) $(p=0.0001)$. Our study shows that the greater the degree of chest deformity, the poorer the pulmonary function. When investigating the effect of chest deformity on spirometric values, we found a significant relationship between the deformity rate and the respiratory spirometric parameters: forced expiratory volume per second $\left(\mathrm{FEV}_{1}\right)$, maximal expiratory flow rate of 50\% (MEF50) and 75\% (MEF75), and peak expiratory flow rate (PEF).

Our study did not show a statistically significant difference in physical activity levels in groups with varying degrees of chest deformity. Similar findings were presented by Zuidema et al. [21], where patients, divided into 
groups according to the severity of the deformity (Haller index $<3.2$ versus $>3.2$ ), did not show a statistically significant difference in the level of sports activity.

The results of our study indicate a lower overall level of physical activity (median 1510 MET-min/wk.) compared to peers in studies presenting similar issues in a sample of healthy populations. The study of Fagaras et al. [31] evaluated the level of physical activity of university students. The study was conducted on a total of 333 students with an average age of $21.05 \pm 1.98$ years. The median values for overall physical activity in men (university students - specialization in physical education and physical therapy) were 5993.92 \pm 2345.19 METmin/wk. Physical activity levels were measured using IPAQ. Bergier et al. [32] found that the median weekly physical activity of Polish university students was 2.611.00 MET - min. It should be emphasized that in our surveyed group, the selected persons did not even reach the minimum recommended WHO level of physical activity (600 MET min/wk.) [33]. This group is at an elevated risk of disorders related to insufficient motor activity [1-3]. The causes of the current situation should be examined in future. It is questionable whether the reduced level of physical activity is due to the symptoms of the disease affecting the exercise of physical activity, or whether economic growth leads to an increasingly sedentary lifestyle of students.

Zuidema et al. [21] followed the sporting activities of adolescents with chest deformity pectus excavatum in the Netherlands. Measurements were made before and 12 months after corrective surgery. Preoperatively, 67\% of the study group was engaged in sports activities; 12 months postoperatively, this percentage remained mostly the same with $65 \%$ of the patients still participating in sporting activity [21]. In the group of patients surveyed by us, $69 \%$ reported that in early and middle adolescent they engaged in regular organized sports activity.

The results of our study indicate that the level of physical activity positively affects pulmonary function. The results showed that the values of spirometric parameters statistically significantly correlate with the level of physical activity of the surveyed respondents. IVC, FVCex, and FEV values correlate positively with higher overall physical activity levels. Other studies comparing respiratory function among healthy men engaged in various sports found that sportsmen have higher levels of function than sedentary people [34-36]. Similarly, Luzak et al. [6] measurements of physical activity showed a weak, but positive association with slightly higher volumetric lung function indices in lung-healthy adults. At the same time, physical inactivity is associated with lower pulmonary function [6].

Our research shows the positive influence of vigorous and moderate physical activity on the pulmonary function of patients with pectus excavatum. A study by Fuertes et al. [37] confirmed that leisure-time vigorous

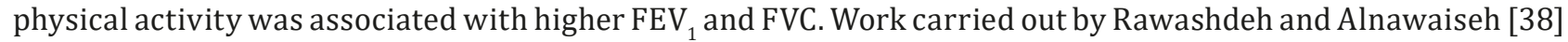
confirmed that high-intensity physical activity is associated with higher $\mathrm{FEV}_{1}$, maximal voluntary ventilation (MVV), and $\mathrm{FEV}_{1} / \mathrm{FVC}$.

Pelkonen et al. [10] found that a group of active subjects had higher $\mathrm{FEV}_{1}$ and FVC than inactive peers. GarciaAymerich et al. [39] conducted a comparative study on the effect of physical activity on pulmonary function over a period of 19 months. In the group of men who preferred an active lifestyle, improvements in FEV 1 and FVC were

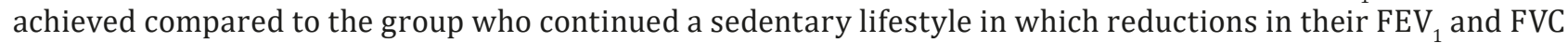
were observed. Similar results were obtained in study Chang et al. [40], persons who remained active had higher $\mathrm{FEV}_{1}$ and FVC than persons who remained or became sedentary.

The present analyses revealed positive correlation between length sporting activity during early and middle adolescence with IVC, FVCex, FEV 1 , MEF75, and PEF. The study of Hancox and Rasmussen [41] showed that improving fitness during childhood and adolescence is associated with higher lung volumes in adults. Similarly, the Menezes study [42] indicated that the level of physical activity in 11 to 15-year-old children was associated with better parameters of pulmonary function.

$35 \%$ of respondents in the monitored group smoke cigarettes; pulmonary function was not affected by smoking in this patient group. It is imperative to encourage patients to avoid this habit, particularly younger individuals, as cigarette smoking is associated with mild airway obstruction and slowed growth of lung function in adolescents [43]. A study by Bird and Staines-Orozco [44] show that that initiation of cigarette smoking in adolescence leads to increased respiratory symptoms and reduction of pulmonary function test values.

In the group of patients studied, most of the respondents had a congenital type of deformity - pectus excavatum, however there were also individuals with pectus excavatum with scoliosis. Omaník et al. [45] and Kokavec and Novorolský [46] report that more than $20 \%$ of patients with pectus excavatum also have associated idiopathic scoliosis or spinal kyphoscoliosis. Tomaszewski et al. [47] have shown that deformation of the anterior thoracic wall promotes rotation of the thoracic spine. Our study did not show a statistically significant difference in physical activity levels in groups of subjects depending on chest deformity. Similar results were seen by Diabakerli et al. [48], in that adolescents with and without idiopathic scoliosis have similar self-reported levels of physical activity. 


\section{Study limitations}

The limitations of the study include the low number of patients examined, as well as the absence of patients with significant chest wall deformity; future studies should address this point.

\section{Conclusions}

We have demonstrated that physical activity can positively affect pulmonary function of patients with pectus excavatum with mild or moderate chest deformity.

\section{Disclosures and acknowledgements}

We thank the employees of the Center for Preventive and Sports Medicine at the Third Internal Clinic UNLP, Tr. SNP 1, Košice for performing a spirometric examination.

\section{References:}

1. Pedersen BK, Saltin B. Exercise as medicine - evidence for prescribing exercise as therapy in 26 different chronic diseases. Scand J Med Sci Sports. 2015; 25(Suppl 3): 1-72. https://doi.org/10.1111/sms.12581

2. Warburton DER, Nicol CW, Bredin SSD. Health benefits of physical activity: the evidence. CMAJ. 2006; 174(6): 801-809. https://doi.org/10.1503/cmaj.051351

3. Macera CA, Hootman JM, Sniezek JE. Major public health benefits of physical activity. Arthritis Rheum. 2003; 49(1): 122-128. https://doi.org/10.1002/art.10907

4. World Health Organization. Global recommendations on physical activity for health. Geneva: World Health Organization; 2010.

5. Lee IM, Shiroma EJ, Lobelo F, Puska P, Blair SN, Katzmarzyk PT. Impact of physical inactivity on the world's major non-communicable diseases. Lancet. 2012; 380(9838): 219-229. https://doi.org/10.1016/S0140-6736(12)61031-9

6. Luzak A, Karrasch S, Thorand B, Nowak D, Holle R, Peters A, et al. Association of physical activity with lung function in lung-healthy German adults: results from the KORA FF4 study. BMC Pulm Med. 2017; 17: 215. https://doi.org/10.1186/s12890-017-0562-8

7. Courteix D, Obert P, Lecoq AM, Guenon P, Koch G. Effect of intensive swimming training on lung volumes, airway resistance and on the maximal expiratory flow-volume relationship in prepubertal girls. Eur J Appl Physiol Occup Physiol. 1997; 76(3): 264-269. https://doi.org/10.1007/s004210050246

8. Almeida VP, Ferreira AS, Guimarães FS, Papathanasiou J, Lopes AJ. The impact of physical activity level, degree of dyspnoea and pulmonary function on the performance of healthy young adults during exercise. J Bodyw Mov Ther. 2019; 23(3): 494-501. https://doi.org/10.1016/j.jbmt.2018.05.005

9. VedalaSR, PaulN, Mane AB. Differencein pulmonary function testamong the athletic and sedentarypopulation. Natl J Physiol Pharm Pharmacol. 2013; 3(2): 118-123. https://doi.org/10.5455/njppp.2013.3.109-114

10. Pelkonen M, Notkola IL, Lakka T, Tukiainen HO, Kivinen P, Nissinen A. Delaying decline in pulmonary function with physical activity: a 25-year follow-up. Am J Respir Crit Care Med. 2003; 168(4): 494-299. https://doi.org/10.1164/rccm.200208-9540C

11. Jakes RW, Day NE, Patel B, Khaw KT, Oakes S, Luben R, et al. Physical inactivity is associated with lower forced expiratory volume in 1 second: European Prospective Investigation into Cancer-Norfolk Prospective Population Study. Am J Epidemiol. 2002; 156(2): 139-47. https://doi.org/10.1093/aje/kwf021

12. Bartl V. [Chest defects]. In: Poul J., ed. [Pediatric orthopaedics]. $1^{\text {st }}$ edition. Praha: Galén; 2009. p. 79-81 (in Czech).

13. Jaroszewski D, Notrica D, McMahon L, Steidley DE, Deschamps C. Current management of pectus excavatum. A review and update of therapy and treatment recommendations. J Am Board Fam Med. 2010; 23(2): 230-239. https://doi.org/10.3122/jabfm.2010.02.090234

14. Jaroszewski DE, Ewais MM, Chao CJ, Gotway MB, Lackey JJ, Myers KM, et al. Success of minimally invasive pectus excavatum procedures (modified nuss) in adult patients ( $\geq 30$ years). Ann Thorac Surg. 2016; 102(3): 993-1003. https://doi.org/10.1016/j.athoracsur.2016.03.105

15. Siman J, Cingel V. [Congenital chest wall deformities]. In: Haruštiak S, Kothaj P, Pechan J, Vajó J, Siman J., eds. [Principles of surgery II]. $1^{\text {st }}$ edition. Bratislava: SAP; 2010. p. 577- 602 (in Slovak). 
16. Kelly RE, Obermeyer RJ, Nuss D. Diminished pulmonary function in pectus excavatum: from denying the problem to finding the mechanism. Ann Cardiothorac Surg. 2016; 5(5): 466-475. https://doi.org/10.21037/acs.2016.09.09

17. Kelly RE, Goretsky MJ, Obermeyer R, Kuhn MA, Redlinger R, Haney TS, et al. Twenty-one years of experience with minimally invasive repair of pectus excavatum by the Nuss procedure in 1215 patients. Ann Surg. 2010; 252(6): 1072-1081. https://doi.org/10.1097/SLA.0b013e3181effdce

18. Chan JY, Huang WL. Objective effect manifestation of pectus excavatum on load-stressed pulmonary function testing: a case report. J Med Case Reports. 2011; 5(1): 592. https://doi.org/10.1186/1752-1947-5-592

19. Rowland T, Moriarty K, Banever G. Effect of pectus excavatum deformity on cardiorespiratory fitness in adolescent boys. Arch Pediatr Adolesc Med. 2005; 159(11): 1069-1073. https://doi.org/10.1001/archpedi.159.11.1069

20. Fonkalsrud EW, Beanes S. Surgical management of pectus carinatum: 30 years' experience. World J Surg. 2001; 25(7): 898-903. https://doi.org/10.1007/s00268-001-0048-x

21. Zuidema WP, Oosterhuis JWA, Zijp GW, van Baren R, de Lange-de Klerk ESM, van der Heide SM, et al. Sports activity in adolescents in the Netherlands with a pectus excavatum; the impact of surgery. J Pediatr Surg. 2019; 54(8): 1671-1674. https://doi.org/10.1016/j.jpedsurg.2018.11.004

22. Steinmann C, Krille S, Mueller A, Weber P, Reingruber B, Martin A. Pectus excavatum and pectus carinatum patients suffer from lower quality of life and impaired body image: a control group comparison of psychological characteristics prior to surgical correction. 2011; 40(5): 1138-1145. https://doi.org/10.1016/j.ejcts.2011.02.019

23. Kelly RE, Daniel A. Outcomes, quality of life, and long-term results after pectus repair from around the globe. Semin Pediatr Surg. 2018; 27(3): 170-174. https://doi.org/10.1053/j.sempedsurg.2018.05.003

24. Frydrychová M. [Congenital chest defects]. In: Dungl P., editor. [Orthopedics]. 2nd edition. Praha: Grada; 2014. p. 439-441 (in Czech).

25. Paul H, Lee PH, Macfarlane DJ, Lam THH, Sunita M, Stewart SM. Validity of the International Physical Activity Questionnaire Short Form (IPAQ-SF): a systematic review. International Journal of Behavioral Nutrition and Physical Activity. 2011; 8(1): 115. https://doi.org/10.1186/1479-5868-8-115

26. Lee IM, Shiroma EJ, Lobelo F, Puska P, Blair SN, Katzmarzyk PT. Impact of physical inactivity on the world's major non-communicable diseases. Lancet. 2012; 380(9838): 219-229.

https://doi.org/10.1016/S0140-6736(12)61031-9

27. Rimarčík M. [Statistics for practice]. Košice: Marián Rimarčík; 2007 (in Slovak).

28. Lawson ML, Mellins RB, Paulson JF, Shamberger RC, Oldham K, Azizkhan RG, et al. Increasing severity of pectus excavatum is associated with reduced pulmonary function. J Pediatr. 2011; 159(2): $256-261$. https://doi.org/10.1016/j.jpeds.2011.01.065

29. Abu-Tair T, Turial S, Hess M, Wiethoff CM, Staatz G, Lollert A, et al. Impact of pectus excavatum on cardiopulmonary function. Ann Thorac Surg. 2018; 105(2): 455-460. https://doi.org/10.1016/j.athoracsur.2017.09.037

30. Morshuis W, Folgering H, Barentsz J, van Lier H, Lacquet L. Pulmonary function before surgery for pectus excavatum and at long-term follow-up. Chest. 1994; 105(6): 1646-1652 https://doi.org/10.1378/chest.105.6.1646

31. Fagaras SP, Radu LE, Vanvu G. The level of physical activity of university students. Procedia - Social and Behavioral Sciences. 2015; 197: 1454-1457. https://doi.org/10.1016/j.sbspro.2015.07.094

32. Bergier J, Kapka L, Biliński P, Wojtyła A. Physical activity of Polish adolescents and young adults according to IPAQ: a population based study. Ann Agric Environ Med. 2012; 19(1): 109-115.

33. Pastuszak A, Lisowski K, Lewandowska J, Buśko K. Level of physical activity of physical education students according to criteria of the IPAQ questionnaire and the recommendation of WHO experts. Biomedical Human Kinetics. 2014; 6(1): 5-11. https://doi.org/10.2478/bhk-2014-0002

34. Almeida VP, Ferreira AS, Guimarães FS, Papathanasiou J, Lopes AJ. The impact of physical activity level, degree of dyspnoea and pulmonary function on the performance of healthy young adults during exercise. J Bodyw Mov Ther. 2019; 23(3): 494-501. https://doi.org/10.1016/j.jbmt.2018.05.005

35. VedalaSR, PaulN, ManeAB. Difference in pulmonary function testamong the athletic and sedentarypopulation. Natl J Physiol Pharm Pharmacol. 2013; 3(2): 118-123. https://doi.org/10.5455/njppp.2013.3.109-114

36. Courteix D, Obert P, Lecoq AM, Guenon P, Koch G. Effect of intensive swimming training on lung volumes, airway resistance and on the maximal expiratory flow-volume relationship in prepubertal girls. Eur J Appl Physiol Occup Physiol. 1997; 76(3): 264-269. https://doi.org/10.1007/s004210050246 
37. Fuertes E, Carsin AE, Antó JM, Bono R, Corsico AG, Demoly P, et al. Leisure-time vigorous physical activity is associated with better lung function: the prospective ECRHS study. Thorax. 2018; 73(4): 376-384. https://doi.org/10.1136/thoraxjnl-2017-210947

38. Rawashdeh A, Alnawaiseh N. The effect of high-intensity aerobic exercise on the pulmonary function among inactive male individuals. Biomed. Pharmacol. J. 2018; 11(2): 735-741. https://doi.org/10.13005/bpj/1427

39. Garcia-Aymerich J, Lange P, Benet M, Schnohr P, Antó JM. Regular physical activity modifies smoking-related lung function decline and reduces risk of chronic obstructive pulmonary disease: a population-based cohort study. Am J Respir Crit Care Med. 2007; 175(5): 458-463. https://doi.org/10.1164/rccm.200607-8960C

40. Cheng YJ, Macera CA, Addy CL, Sy FS, Wieland D, Blair SN. Effects of physical activity on exercise tests and respiratory function. Br J Sports Med. 2003; 37(6): 521-528. https://doi.org/10.1136/bjsm.37.6.521

41. Hancox RJ, Rasmussen F. Does physical fitness enhance lung function in children and young adults?. Eur Respir J. 2018; 51(2): 1701374. https://doi.org/10.1183/13993003.01374-2017

42. Menezes AM, Wehrmeister FC, Muniz LC, Perez-Padilla R, Noal RB, Silva MC, et al. Physical activity and lung function in adolescents: the 1993 Pelotas (Brazil) birth cohort study. J Adolesc Health. 2012; 51(6 Suppl): S27-31. https://doi.org/10.1016/j.jadohealth.2012.06.023

43. Gold DR, Wang X, Wypij D, Speizer FE, Ware JH, Dockery DW. Effects of cigarette smoking on lung function in adolescent boys and girls. N Engl J Med. 1996; 335(13): 931-937. https://doi.org/10.1056/ NEJM199609263351304

44. Bird Y, Staines-Orozco H. Pulmonary effects of active smoking and secondhand smoke exposure among adolescent students in Juárez, Mexico. Int J Chron Obstruct Pulmon Dis. 2016; 11: 1459-1467. https://doi. org/10.2147/COPD.S102999

45. Omaník P, Schlanková N, Béder I, Kabát M, Trnka J. [Anterior chest wall deformities in children]. Pediatr. Prax. 2018; 19(3): 106-110 (in Slovak).

46. Kokavec M, Novorolský K. [Scoliosis and physical activity in children]. Pediatr. Prax. 2007; 8(2): 70-74 (in Slovak).

47. Tomaszewski R, Wiktor $七$, Machała L. Evaluation of thoracic vertebrae rotation in patients with pectus excavatum. Acta Orthop Traumatol Turc. 2017; 51(4): 284-289. https://doi.org/10.1016/j.aott.2017.03.005

48. Diarbakerli E, Grauers A, Möller H, Abbott A, Gerdhem P. Adolescents with and without idiopathic scoliosis have similar self-reported level of physical activity: a cross-sectional study. Scoliosis Spinal Disord. 2016; 11: 17. https://doi.org/10.1186/s13013-016-0082-y 